Agata Kawecka

Rafał Zarębski (Łódź)

\title{
Linguistic Equivalence of The Hebrew Term Eden in Slavic Translations of The Bible ${ }^{1}$
}

\begin{abstract}
A thought expressed by Irena Kwilecka, a prominent researcher of early Polish, Czech and French translations of the Bible, constitutes an appropriate introduction to the divagations included in this dissertation. Kwilecka wrote that

the text of the Bible poses an exceptionally formidable challenge for a translator, since its original version was written in chunks, and many ages ago, was drafted by various authors, and contained numerous literary genres, i.e. it was a creation of a separate and very old culture. Additionally, since the Bible contains references to the majority of issues related to political, social and economic life in the past, including politics, social issues, economy, trade, craft, art, philosophy, religion, and the knowledge of plant and animal life, it not only requires the translator to be a skilful language expert and linguist, but also an erudite, perfectly familiar with the state of contemporary general knowledge ${ }^{2}$.
\end{abstract}

The interpretation of the Books of the Bible was particularly challenging for the authors of older translations, including Slavic versions. The most problematic issue was how to comprehensibly present the reality of the Hamito-Semitic culture, which gave birth to the Bible, since the culture was so distant and unknown to the target reader of any translation. Problems stemmed not only from the genetic, systematic and lexical differences between the languages of the Bible and the Slavic Indo-European tongues, but also from the discrepancy in the spheres of mentality and conceptuality. Over time subsequent generations of translators began to solve such issues by seeking assistance and inspiration in the translations made into other languages and versions prepared by their predecessors. As is commonly known, authors of virtually any biblical translation utilise - to a greater or lesser extent

\footnotetext{
${ }^{1}$ The publication was released as part of the project called Reception of the Literary Output and Folk Culture of the Slavia Orthodoxa circle in Poland - the History and Bibliography of the Translation Production (Recepcja piśmiennictwa oraz literatury ludowej kregu Slavia Orthodoxa w Polsce - historia i bibliografia twórczości przekładowej) and implemented at the Ceraneum Centre, the University of Łódź. The project was financed by the National Science Centre, decision number DEC-2012/05/E /HS2/03827.

${ }^{2}$ I. KwILECKA, Średniowieczna Biblia francuska a najstarsze zachodniosłowiańskie przekłady biblijne, [in:] EADEM, Studia nad staropolskimi przekładami Biblii, Poznań 2003, p. 153-175 (153).
} 
- the translation tradition. Nowadays this approach is also universally applied, even though our pool of knowledge in the field of biblical philology is incomparably more advanced than in the times of the first Slavic translations.

The Bible opens a wide spectrum of research opportunities for various branches of science, including philological divagations in the first place. Its original text has been the subject of great scientific interest since ancient times; initially, however, the issue of translation into particular languages drew researchers' attention in the context of their role in shaping literary languages.

Proper names in translations of the Bible are a particularly absorbing area of research, although it must be emphasised that initially the focus was, for obvious reasons, on proper names within the original text, with particular attention paid to the explanation of their origins. Among ancient researchers who were involved in studies over this aspect of linguistics, it is noteworthy to mention Philo of Alexandria (40 C.E.), even if his research work did not possess a significantly substantial value, since he sought Greek roots in foreign Hebrew names and, on such a basis, he also attempted to explain the genesis of these names. Another work which should also be quoted here is Antiquitates iudicae by Titus Flavius Josephus (100 C.E.), the content of which was actually distorted by the actions of the author himself, as he never went beyond adding Greek suffixes to Hebrew names (e.g. Abraham $>$ Abramos). Other scientists who also showed a keen interest in biblical etymology were Christian researchers such as Origen, Saint Jerome and Eusebius of Caesarea. The results of their research work related to the said scope of interest were included in the compendium entitled Onomastica sacra, compiled by Paul de Lagarde, with a philological survey and supplements by Franz Wutz.

In the Middle Ages and the Renaissance, a great interest was taken in biblical names by such scholars as i.a. Joseph ben Simson, Nicholas of Lyra, Alfonso de Zamora, Santes Pagnino, Georg Witzel, Drusus of Leiden, Johannes Leusden, Jan Simson. On the one hand, they focused on etymologising nomina propria, and on the other hand, on registering them in various onomasticons. At that time, however, a thoroughly scientific and multi-faceted research on the origins and the morphological structure of biblical names was unfeasible, due to the lack of compendia on Hebrew grammar, which was released no earlier than in the $19^{\text {th }}$ century. The works by Gesenius, Ewald and Olshausen on the system of Hebrew language resulted in a breakthrough in the field of biblical onomastics. It is when more significant publications began to appear, mainly by Nestle, Grunwald, Kerber, Hommel and Gray. These scholars scrutinised biblical names against a broader Semitic background, by applying the historical and comparative approach, which allowed them to indicate various linguistic relations between Hebrew, Babylonian and Egyptian names ${ }^{3}$.

${ }^{3}$ Cf. A. KlaweK, Onomastyka biblijna, On 7, 1961, p. 403-416. 
The perspective of onomastic research of translations is noticeably different when compared to studies of the names within the original text of the Bible, since the focus is shifted from the etymology and the linguistic structure of names to the description of methods in which they function in the translated text, with particular attention paid to the issues related to the linguistic adaptation of proper names.

By and large, nomina propria may find their way into the translation in three forms, which substantially depends on the strategy the translator opts for ${ }^{4}$. The simplest approach is to transfer names in the so-called translocated form, i.e. carried from the original text in their unchanged form. One can speak of a full and complete translocation only if both the language of the original and the translation uses an alphabet based on a similar source. Thus, in the case of biblical translations, full translocation is possible between the Latin Vulgate (cetera: VG) ${ }^{5}$ and translations into Western European languages (e.g. French, Italian, Spanish, English and German) and some Slavic tongues (e.g. Polish, Czech, Slovak and Slovenian). Translocation was a commonly applied technique in reference to names in the earliest Slavic translations of the Bible, since its translators experienced great linguistic difficulties as far as some names were concerned. This process most frequently consisted in transferring any given form of the foreign oblique case from the base text into the translation without any formal changes, e.g. do Derben (< Greek: $\Delta \varepsilon \dot{\varepsilon} \beta \beta \eta$, Latin: in Derben $)^{6}$ (Act 14,20) (the Leopolita's Bible) ${ }^{7}$.

The second and the least complex solution applied to proper names in translation is their linguistic adaptation. This can be performed only either on the graphic and phonetic layer or on the morphological surface (inflectional and word-formative). Another alternative is to perform it on both levels at the same time. If the process of name translocation is accompanied by the change of alphabet, we can speak about the graphic adaptation, e.g. do Derben (< Greek: $\Delta \dot{\varepsilon} \rho \beta \eta v)$. In the biblical translations into Slavic languages, adaptation is usually performed simultaneously on numerous surfaces. The accommodation of phonetics and spelling of names to individual languages, due to their inflectional nature, is often combined with inflectional adaptation, and more often than not also with word-forming adaptation (particularly in reference to derivative forms of any given names, i.e. nouns and adjectives used to describe names of inhabitants or locative adjectives).

The most comprehensive phase of adapting any given name into another language system is its translation. Generally, there is a tendency to emphasise the untranslatability of proper names, as they primarily identify and nominate an object, without possessing any lexical meaning. In the Bible, however, proper

${ }^{4}$ Cf. A. Cieślıkowa, Jak „ocalić w tłumaczeniu” nazwy własne?, [in:] Między oryginałem a przekładem II. Przekład, jego tworzenie się i wplyw, ed. J. Twardzikowa, M. Filipowicz-Rudek, Kraków 1996, p. 311-320.

${ }^{5}$ Biblia Sacra Vulgata, http://www.drbo.org/lvb/ [20 IV 2016].

${ }^{6}$ As cited in: Novum Testamentum Graece et Latine, ed. E. Nestre, K. Aland, Stuttgart 1984.

${ }^{7}$ Leopolita's Bible is based on the VG. 
names are often of greater importance, since they frequently have a wider purpose than just to identify objects. On numerous occasions, biblical proper names play a symbolic role, as they can characterise the denoted object in terms of ideology. Occasionally, names must be translated due to the theandric nature of the text, related to the fact that Hebrew names were an expression of faith (cf. numerous biblical theophoric names, e.g. Elimelek 'mój Bóg jest królem/My God is King', Ezechiel 'Jahwe umocnił/God strengthens', Izajasz 'niech Bóg cię ocali/Yah is salvation' $)^{8}$. The semantics of appellatives which are present in the background of some names is so important for the global message of the biblical text that it forces translators to refer to the semantic equivalent in the target language.

The issue of translating biblical names is complex and multi-faceted. Theoretically speaking, each name can be translated, because it is the appellative lexis that lies in its foundations. Only some names, however, are actually translated (in particular, the ones burdened with a greater symbolic load). This procedure was already implemented in the first translations of the Bible, as proven by some names translated in the Septuagint (cetera: LXX) ${ }^{9}$ and the VG. Attempts were made to translate some Hebrew names, which were asemantic in Greek and Latin, in order to

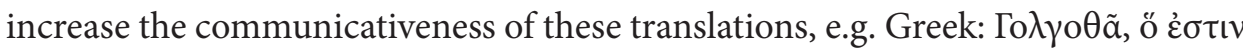
краvíov то́ Some names were only translated in the VG (or they were explained, often with the application of a metalinguistic formula which introduced the Latin semantic equivalent, e.g. quod est, quod interpretatur, etc.), and they were left untranslated in the Greek version, e.g. Saphaneth Phanec (quod interpretatur Salvator mundi)

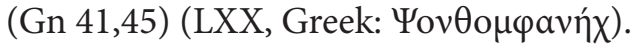

The practices and approaches implemented in reference to proper names in the earliest translations of the Bible (i.e. Greek and Latin) have had a substantial influence upon the names used in other language versions. This is so because the translation base is one of the most significant extra-linguistic factors which determine the final shape of any given translation. And when one takes into consideration the fact that this shape is also impacted by other extra-linguistic factors such as the approach to translation (philological, liberal, literal, dynamic, ecumenical, poetic, etc.), the attitude towards the translation tradition (patterning oneself on the decisions made by predecessors, breaking with the translation traditions within any given national language systems, a creative dialogue with such traditions, etc.), and religious conditionings in which a particular translation was made, it will turn out that the onomastic problems within any given translation constitute an extremely elaborate and complex issue. The final shape of any name is the resultant of various

\footnotetext{
${ }^{8}$ O. Odelain, R. Séguineau, Dictionnaire des noms propres de la Bible, Paris 1978.

${ }^{9}$ Septuaginta, ed. A. RaHLFs, ${ }^{9}$ Stuttgart 1971, http://www.ellopos.net/elpenor/physis/septuagintgenesis/41.asp?pg=5 [21 IV 2016].

${ }^{10}$ The Greek text as cited in: Novum Testamentum Graece et Latine..., and the Latin text after the VG.
} 
factors of a linguistic and extra-linguistic nature, which renders the subject of names in biblical translations to be an attractive and yet quite challenging research problem.

The translation of biblical proper names can be scrutinised from various research perspectives. Some scholars signal the complexity of issues and methodological difficulties ${ }^{11}$, while others show a keener interest in the issues related to the linguistic adaptation of genetically foreign proper names ${ }^{12}$ or the influence of extra-linguistic factors upon the final form of the names in various translations of the Bible ${ }^{13}$. Linguists also focus on the onomastics of specific examples of translations ${ }^{14}$, selected books of the Bible ${ }^{15}$, and the stipulated onomastic category (anthroponyms, toponyms) ${ }^{16}$. Sometimes studies centre on a very limited issue (e.g. a single name), which not only impacts the final linguistic and stylistic form of the translation, but it also allows the researcher to demonstrate methodological difficulties and the research complexity of the translation itself ${ }^{17}$. From the methodological perspective, the study presented in this article is of similar nature.

The purpose of this publication is to scrutinise the translation equivalents of the name Eden ('rozkosz/pleasure') in selected - old and contemporary - Slavic translations of the Bible. The rationale behind focusing on this particular name

\footnotetext{
${ }^{11}$ M. KAmiŃsKa, Onomastyka biblijna tekstów przekładowych jako problem badawczy, [in:] Onomastyka literacka, ed. M. BıоLIK, Olsztyn 1993, p. 321-328.

${ }^{12}$ E. Breza, Odmiana nazw własnych w Nowym Testamencie Biblii Wujka i Biblii Tysiaclecia, [in:] Biblia a kultura Europy, vol. I, ed. M. KamińsKa, E. MAŁEK, Łódź 1992, p. 152-159; F. Sowa, Osobowe nazwy własne w polskich przekładach Biblii, [in:] Biblia a kultura Europy..., p. 81-85; M. MALEC, Onomastyka w „Rozmyślaniu przemyskim”, Po 22-23, 2003, p. 345-390.

${ }^{13}$ D. BieŃкоwsкA, O niektórych problemach przekładu biblijnego (na przykładzie miast, miasteczek i wsi), [in:] Biblia w kulturze polskiej, ed. S. RzEPCZYŃski, Słupsk 1996, p. 215-228.

${ }^{14}$ K. DŁugosz-Kurczabowa, Onomastyka Nowego Testamentu, SOcc 46-47, 1989-1990, p. 71-88; E. UmińsкA-TyтоŃ, Nazwy osobowe w tzw. dynamicznym przekładzie Nowego Testamentu, [in:] Onomastyka literacka..., p. 329-335; L. Moszyński, Szymon Budny jako onomasta. 3. Ojkonimia, [in:] Ogród nauk filologicznych. Księga Jubileuszowa poświęcona Profesorowi Stanisławowi Kochmanowi, ed. W. Chlebda, M. Balowski, Opole 2005, p. 445-455.

${ }^{15}$ S. Rospond, Onomastica sacra. 3. Ewangelia św. Mateusza w świetle nazewnictwa, RHu 30-31.6, 1982-1983, p. 183-191; IDEM, Onomastica sacra w Nowym Testamencie: Ewangelia św. Marka w świetle nazewnictwa, On 27, 1983, p. 5-32; T. FrIEdELównA, Biblijna onomastyka w staro-cerkiewno-słowiańskim Psatterzu synajskim, AUNC.FP 40, 1993, p. 3-25.

${ }^{16}$ D. BIEŃKowsKa, Nazwy własne i formy od nich derywowane w XVI-wiecznych przekładach tekstów ewangelicznych, AUL.FL 27, 1993, p. 9-14; K. KomÁreK, Osobní jména v českých biblích, Olomouc 2000; R. DitTmann, Místní jména v českých préekladech Starého zákona, Olomouc 2009; R. ZARĘBSKI, Nazwy osobowe w polskich przekładach Nowego Testamentu, Łódź 2006; IDEM, Tłumaczenie obcych nazw geograficznych $w$ dawnych $i$ współczesnych polskich przekładach Nowego Testamentu, [in:] Studia nad słownictwem dawnym $i$ współczesnym języków słowiańskich, ed. J. KaMPER-WAREJKO, I. Kaproń-Charzyńska, J. Kulwicka-Kamińska, Toruń 2007, p. 113-123; idem, Номинации с определителна филиативна дескрипиия в Зографския кодекс на фона на някои славянски преводи на Евангелието, Pbg 37.4, 2013, p. 81-94.

${ }^{17}$ L. MoszyŃski, Hebr. ha - Adam: nomen apellativum - nomen proprium w renesansowych przekładach biblijnego opisu życia pierwszego człowieka (Gen I 26 - V5), Sla 61, 1992, p. 503-508.
} 
is that even in the original text of the Bible its status was quite ambiguous (as it alternated between the function of a common and proper name, being noticeably closer to the latter). In the $\mathrm{VG}^{18}$, however, it was translated into paradisium voluptatis (Latin), which highlighted its appellative nature and stemmed, to a substantial extent, from the ambiguous interpretation of this lexical item in the Bible itself $^{19}$. Such discrepancies resulted in a certain chaos in translations, where the name appears in the form of various equivalents. Another factor determining the selection of philological study of the Hebrew Eden was the fact that the name was burdened with a heavy symbolic load in the original text. Such conditions led to the peculiar manner in which it also functions in contemporary Slavic languages (and some non-Slavic as well) ${ }^{20}$.

'Equivalence' in translation is understood as a state in which two constituents (the source and its translation) possess the same value or are identical in terms of function and effects of co-operation. The relatedness of sameness may occur between morphological, lexical, syntactic and semantic elements. In consequence, the source text is transformed into the target one, and there is a relationship between the two, which can be called the relation of equivalence ${ }^{21}$.

The ambiguous nature of the name Eden, alternating between its appellative and proper dimension, as well as the dilemmas experienced by various translators of the Bible requires that the researcher scrutinise the name and its translation variants also in the context of such phenomena as properisation (onimisation) and appellativisation (deonimisation, deproprialisation). The division of vocabulary within any natural language into common and proper names had already been made in Antiquity, and as early as the times of Aristotle. Due to the fact that the Bible is characterised by the abundance of literary genres and figures of speech (epithets, metaphors, synecdoche, metonymies, allegories, personifications and depersonifications, periphrases, ironies, hyperboles, etc.), numerous names within its content contain certain religious truths, which ought to be explained in the original and must be clarified in the translation. This phenomenon is related to the fluctuant nature of many biblical names, since - as mentioned above - they can function both as propria and appellativa ${ }^{22}$. Thus, the process of appellativisation is understood as the transformation of a proper name into the class of common names. As stated by Długosz-Kurczabowa:

\footnotetext{
${ }^{18}$ In the Biblia Sacra Vulgata the name Eden appears only in Gn 4,16: ad orientalem plagam Eden (Latin), cf. K. КомÁreк, Apelatywizacja w toponimii biblijnej, [in:] Onimizacja i apelatywizacja, ed. Z. Abramowiczowa, E. Bogdanowicz, Białystok 2006, p. 113-117.

${ }^{19}$ Ibidem.

${ }^{20}$ This issue is not the subject of the analysis herein.

${ }^{21} \mathrm{Cf}$. W. Osadniк, Teoria wielosystemowa i rodzaje ekwiwalencji w przekładzie, Katowice 2010, p. 86.

${ }^{22}$ It is noteworthy to add that biblical names tend to become common words when outside the biblical text, in other national languages, e.g. Judasz > judasz in Polish (English: Judas) means 'zdrajca/a traitor' or 'wizjer/a peephole. Eden is also such a word, as it may mean 'miejsce szczęśliwe/a place
} 
the essence of appellativisation is based on the fact that out of many constituents of the onomastic meaning within any given name, one begins to dominate - it may be accidental and of minor importance - and becomes the base of the lexical meaning ${ }^{23}$.

Proprialisation, on the other hand, is related to the loss of features of the predicate of the word. Both in the process of onimisation and appellativisation the function of a word (a name) undergoes a change, which is always accompanied by semantic derivation ${ }^{24}$.

The transaction equivalents of the Hebrew name Eden have been excerpted from the Slavic versions of the Bible, the selection of which was dictated by the concern about the possibly most varied set of criteria ${ }^{25}$. The selected texts have been aligned chronologically, which is manifested in the following oppositions: old translations (from the earliest to the first quarter of the $20^{\text {th }}$ century) (The Olomouc Bible (cetera: OL) ${ }^{26}$, The Kralice Bible (cetera: KR ${ }^{27}$, Queen Sophia's Bible (cetera: KZ) ${ }^{28}$, Leopolita's Bible (cetera: BL), The Brest Bible (cetera: BRZ) ${ }^{29}$, Nesvizh Bible translated by Symon Budny (cetera: BB) ${ }^{30}$, Jakub Wujek's Bible (cetera: BW) ${ }^{31}$, The Bible translated by Francisk Skorina (cetera: FS) ${ }^{32}$, The Ostrog Bible (cetera:

of happiness'. Cf. K. Deugosz-Kurczabowa, Apelatywizacja biblijnych nazw własnych w języku polskim, Wrocław-Warszawa-Kraków 1990, p. 5-11, 31-32, 43-44.

${ }^{23}$ Ibidem, p. 5-11, 69.

${ }^{24}$ A. Cieślıkowa, Onimizacja, apelatywizacja a derywacja, [in:] Onimizacja i apelatywizacja..., p. $47-56$.

${ }^{25}$ It must be emphasised that the selection of texts subjected to excerption is arbitrary. Our desire was to present a relatively wide representation of Slavic translations, even though we do realise this may not be a wide spectrum. Any restrictions were introduced primarily due to the limited length of this article. For comparative purposes, references to the texts are in Hebrew (BH), Greek (LXX) and Latin (VG).

${ }^{26}$ Staročeská bible Dráždanská a Olomoucká: kritické vydání nejstaršího českého překladu bible ze 14. století. 3, Genesis - Esdráš, ed. V. Kyas, Praha 1988.

${ }^{27}$ Bible svatá aneb všecka svatá písma Starého i Nového Zákona podle posledního vydání kralického z roku 1613, http://www.etf.cuni.cz/ rovnanim/bible/k/Mt1.php [21 IV 2016].

${ }^{28}$ Biblia Królowej Zofii (szaroszpatacka): wraz ze staroczeskim przekładem Biblii, ed. S. URBAŃczyK, V. Kyas, Wrocław 1965-1971.

${ }^{29}$ Biblia Swięta tho iest Księgi Starego y Nowego Zakonu, wlaśnie z żydowskiego, greckiego y łacińskiego, nowo na Polski ięzyk z pilnościa y wiernie wyłożone... drukowano w Brześciu Litewskim z roskazania a nakładem... Mikolaia Radziwila... Roku Pańskiego [1563] miesiąca Wrzesnia dnia czwartego, http://mbc.malopolska.pl/dlibra/docmetadata?id=83322\&from= publication [19 IV 2016].

${ }^{30}$ Biblia to jest Księgi starego i Nowego Przymierza. Księgi Nowego Przymierza Kto pospolicie Nowym Testamentem zowa $z$ wielka praca y pilnym poprawieniem $z$ Greckiego na Polski ięzyk przetłumaczone, http://www.dbc.wroc.pl/dlibra/docmetadata?id=4263\&from=publication [10 IV 2016]. ${ }^{31}$ Biblia To Iest Księgi Starego Y Nowego Testamentu, Według Łacińskiego przekładu starego, w kościele powszechnym przyiętego, na Polski ięzyk z pilnościa przełozone [...] Przez [...] Iakuba Wuyka [...], http://www.dbc.wroc.pl/dlibra/doccontent?id=12433 [11 IV 2016].

32 "Библия руска" выложена доктором Франциском Скориною из славного града Полоика, Богу ко чти и людем посполитым к доброму научению, Прага 1517-1519. 
$\mathrm{BO})^{33}$, Gdansk Bible $e^{34}$ (cetera: GD), The Wenceslas Bible (cetera: VA) ${ }^{35}$, The Old Testament translated by Josef Heger (cetera: HG) ${ }^{36}$, The Old Testament translated by Đuro Daničić (cetera: D) ${ }^{37}$, Carigradska Bible (cetera: BC) ${ }^{38}$, the so-called synodic edition of The Bulgarian Bible (cetera: $S)^{39}$ ) versus contemporary ones, drafted in the second half of the $20^{\text {th }}$ century and in the $21^{\text {st }}$ century (Millennium Bible (cetera: BT) ${ }^{40}$, the Czech ecumenical translation (cetera: EK) ${ }^{41}$, The Jerusalem Bible (cetera: JR) ${ }^{42}$ ), geographically linguistic; the selected examples represent three groups of Slavic languages: Western Slavic (BZ, BL, BRZ, BB, BW, GD, BT, OL, KR, VA, HG, EK, JR) ${ }^{43}$, Eastern Slavic (FS, BO) and Southern Slavic (S, BC, $\mathrm{D})$, the division related to the base of the translation: source text and/or Greek version (KR, BRZ, BB, GD, HG, BT, EK, JR, S) versus Latin version (OL, BZ, BL, BW, VA, FS, D), religious: Catholic (OL, BZ, BL, BW, VA, JR), Protestant (KR, $\mathrm{BRZ}, \mathrm{BB}, \mathrm{BC}$ ), Orthodox (FS, BO, S) and also related to the method of translation, since the set of the excerpted examples includes both literal and more liberal translations. At the same time, it ought to be borne in mind that numerous translators applied a combination of various translation strategies. Although the discussed contemporary translations are usually philological in their nature (i.e. translators aim at remaining faithful to the source text of the translation), they are not free of religious influences.

\footnotetext{
${ }_{33}^{33}$ Библия сиречь книги Ветхого и Нового Завета на языке словенском, Острог 1581.

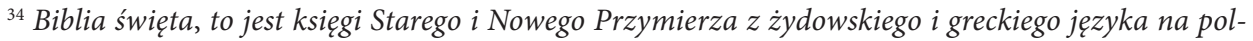
ski pilnie i wiernie przetłumaczone, Gdańsk 1632, http://www.bibliagdanska.pl/biblia. php?d, [12 IV 2016].

${ }^{35}$ BJBLJ Cžeská to gest Swaté Pjsmo Podlé Starožitného a Obecného Latinského od Wsseobecné Cýrkwe Swaté Ržjmské potwrzeného a vžjwaného Přeloženj [...] W Starém Městě Pražském w Kollegi Sw. Kljmenta Towaryšstwa P. Gežjsse skrze Joachyma Jana Kamenického Faktora Léta M. DCC. XV. [= 2. díl] Prorokowé A Knihy Machabeyský. Nákladem Dédictwj Swatého Wáclawa [...] Léta 1712. [= 3. dil] Druhý djl Biblj totižto Nowý Zákon Podlé starého obecného Latinského textu, od samospasytedlné Ržjmské Katoljcké Cýrkwe schwáleného, a až posawad wtéž Cýrkwi vžjwaného [...] Léta Páně 1677 [...] [= 3. díl, NZ].

${ }^{36}$ Písmo svaté Starého zákona, ed. F. Kotalík, J. Merell, Praha 1955-1958.

${ }^{37}$ Biblija ili Sveto pismo Staroga i Novoga zavjeta, http://www.pouke.org/svetopismo/ [15 IV 2016].

${ }^{38}$ Библия, сиреч Священото писание на вехтий и новий завет. Вярно и точно преведено от първообразното, Цариград 1871, http://biblia.bg/index.php?k=30\&g=1\&tr2=1 [16 IV 2016].

${ }^{39}$ Библия, сиреч книгите на Свещеното писание на Вехтия и Новия Завет, http://www.bgpatriarshia.bg/index.php?file=bible_old_testament.xml [16 IV 2016].

${ }^{40}$ Pismo Święte Starego i Nowego Testamentu w przekładzie z języków oryginalnych, ed. K. DyNARsKI, ${ }^{1}$ Poznań 1965, ${ }^{4} 1983$, http://biblia.deon.pl/ [15 IV 2016].

${ }^{41}$ Český ekumenický preklad: Písmo svaté Starého i Nového Zákona podle ekumenického vydání $z$ r. 1985, Praha 1987, http://www.biblenet.cz/ [23 IV 2016].

42 Jeruzalémská bible. Písmo svaté vydané Jeruzalémskou biblickou školou, Praha 2005, http://www. jeruzalemskabible.cz/ [24 IV 2016].

${ }^{43}$ The issue of equivalents of the Hebrew word Eden in Czech translations is scrutinised by R. Dittmann (op. cit., p. 229-232). The examples excerpted from the Czech translations (EK, HG, JR, KR, OL, VA) have been taken from his work.
} 
The name Eden (Hebrew: gan be 'éden) in the Bible is for the first time used in Gn 2,8. In the LXX and VG, gan was translated into paradisus (Latin) (cf. Persian: pairi-deza 'miejsce zamknięte/a closed place'), and the word 'éden was represented by the noun voluptas (Latin) 'rozkosz/pleasure', which finally resulted in paradisus voluptatis (Latin) 'raj rozkoszy/the paradise of pleasure'. However, 'éden in the Bible means 'rozkosz/pleasure' when it is written in plural (Ps 35,9; Ier 51,34). Thus, the use of this word without an article and with a preposition $b^{e}$ (Gn 2,8; 2,10; 2,15; 3,23; 4,16; Ez 28,13; 31,9; 31,16; 31,18; 36,35; Il 2,3) as well as the context make us understand it as a proper name (cf. KR 202). Sometimes the meaning of the word Eden is also related to the Sumerian word edin, which stands for 'pustkowie, równina, step/wilderness, plain, steppe'44.

At first, we shall focus on the translation equivalents of the Hebrew Eden in Gn. This name in The Hebrew Bible (cetera: $\mathrm{BH}$ ) is used six times (Gn 2,8: $\mathrm{E} \delta \varepsilon \mu \mathrm{LXX}$,

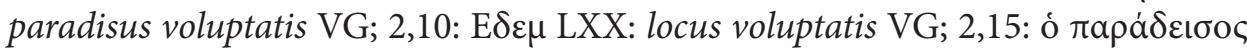

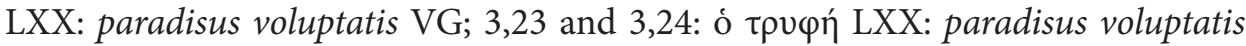
VG; 3,24; 4,16: E $\delta \varepsilon \mu$ LXX, Eden VG). The translations based on the original text are usually quite consistent in that matter and each time the name Eden is used (BRZ, GD, KR, EK, JR, BT), even if they do apply various appellatives to name ogród Eden: ogród ${ }^{45}$ (w) Eden (Gn 2,8; 2,15; 3,23; 3,24), sad ${ }^{46}(w)$ Eden (BRZ, GD). In the case of some translations based on the original text, however, the form of the translation equivalent is influenced by the Greek LXX. Then three types of counterparts are possible: 1$)$ a proper name only, e.g. Едем $(\mathrm{Gn} 2,10 ; 4,16)(\mathrm{S}, \mathrm{BC}, \mathrm{D})$, Eden (BB, HG), 2) appellativum + an adverbial phrase with a noun in the form of proper name, e.g. рай $^{47}$ в Едем (Gn 2,8) (S, BC), врт ${ }^{48}$ у Едему (Gn 2,8) (D),

${ }^{44}$ Eden was identified with a perfect garden of pleasure, i.e. paradise. It is quite difficult to determine the actual location of the garden in Eden. In Gn 2,8 it is placed 'na wschodzie/in the east', which usually means Mesopotamia. In Gn 2,10-14 there is a reference to the Near East tradition, according to which four rivers flow from the idyllic garden (Ogród, [in:] Słownik wiedzy biblijnej, ed. B.M. Metzger, M.D. Coogan, Warszawa 1997, cetera: SWB). Cf. F. Rienecker, G. Maier, Leksykon biblijny, scientifically ed. W. Chrostowski, Warszawa 2001 (cetera: LB).

${ }^{45}$ Ogród - 1. 'teren zajęty pod uprawę warzyw, kwiatów, drzew i krzewów owocowych, zwykle ogrodzony i znajdujący się w pobliżu domu', 2. 'teren służący jako miejsce spacerów dla publiczności, zasadzony drzewami, ozdobiony trawnikami, klombami kwiatów, itp.; park' (Słownik języka polskiego, ed. W. Doroszewski, vol. I-XI, Warszawa 1996-1997).

${ }^{46}$ Sad - 'kawał ziemi, na którym rosną drzewa i krzewy owocowe' (Słownik staropolski, ed. S. URBAŃCZYK, vol. I-XI, Kraków 1953-2002, cetera: Sstp.).

${ }^{47}$ Рaй - M. 1. 'според някои религиозни представи - място, където живеят блажено душите на праведниците след смъртта им', Насила в рая се не влиза. 2. 'прекрасна градина, в която според Библията са живели Адам и Ева до грехояпадението', Изгонване от рая. 3. прен. 'особено красива местност', През пролетта полето е рай. 4. прен. 'място, страна, където може да се живее леко и безгрижно, където за някого или нещо съществуват отлични условия'; 'Земен рай - красива местност' (Български тълковен речник, ed. Д. Попов, София 2001, cetera: BTR). ${ }^{48} \mathrm{Bpm}$ - 1. 'ограђено земљиште на којем се гаји поврће и цвеће' (М. Московљевић, Речник савременог српског језика с језичким саветником, Београд 2000). 
sad Eden (BB), and finally 3 ) the nominal group with a noun derived from the name of Eden, e.g. Едемската градина ${ }^{49}$ (Gen 2,15; 3,23; 3,24) (S), рай Едемски (BC), врт едемски (D), Edenská zahrada ${ }^{50}$ (HG), sad Edeński (BB). At this point, the $16^{\text {th }}$ century translation by Symon Budny $(\mathrm{BB})$ is worth noticing, as the translator, who was aware of the ambiguous onomastic status of the name Eden when it was used for the first time in the Bible (Gn 2,8), provided it with a commentary on the margin:

Eden roznie rozni rozumieją, iedni to apellaciw wykładają, drudzy maią za własne imie Krainy niektorey na wschod słońca leżącey ${ }^{51}$.

In all probability, the search for a compromise between various translation equivalents of the name forced the author to refer to counterparts which accumulate various solutions. Therefore, the phrase sad Edeń(ski) comes as no surprise in $\mathrm{Gn} 2,15$ of $\mathrm{BB}$, which by means of a graphic trick (brackets) combines the noun and adjective form of the name.

In the Latin VG, the name Eden appears in Gn 4,16, and in all other fragments where the Hebrew text (BH) had the toponym Eden, VG follows LXX and offers the equivalent paradisum (Latin). The lexeme paradeisos (Greek), paradisus (Latin) originates from the Old Persian language (Avestan) paridaeza (Persian: pardes, Hebrew: pardes, Aramaic: pardesa) 'park, ogród, ogród rozkoszy/park, garden, garden of pleasure', 'ogrodzone miejsce, obwałowania/enclosed place, rampart'. The word was first used in LXX in reference to the garden in Eden (SWB; $\mathrm{LB})^{52}$. Translations based on the VG are faithful here to the translation base: ray ${ }^{53}$ rofkofzy $y^{54}$ (Gn 2,28; 2,15; 3,23; 3,24) // myafto ${ }^{55}$ rofkofzy (Gn 2,10) (BZ, BW), ráj rozkoši (Gn 2,28; 2,15; 3,23; 3,24) // miesto rozkoši $(\mathrm{Gn} 2,10)(\mathrm{OL})$, ráj rozkoše (VA), раи ${ }^{56}$ коханин (Gn 2,28; 2,15; 3,23; 3,24) (FS) // место кохания (Gn 2,10) (FS)

\footnotetext{
${ }^{49}$ Градина - ж. 'място, засадено с цветя, дървета или зеленчук, обикн. заградено и близо до селището' (BTR).

${ }^{50}$ Zahrada 'ohrazený pozemek, zprav. při obydlích, na kt. se pěstují květiny, zelenina, ovocné i okrasné stromy' (Slovník spisovného jazyka českého, http://ssjc.ujc.cas.cz/search.php?hledej=Hledat\& heslo $=$ zahrada\&sti=EMPTY\&where=hesla\&hsubstr $=$ no [20 IV 2016]).

${ }^{51}$ The word Eden is understood differently by various people - some interpret it as an appellative and others claim it to be the name of a land in the east.

${ }^{52}$ Cf. Encyklopedia katolicka, vol. XVI, ed. S. WiLk, Lublin 2012 (cetera: EKat).

${ }^{53}$ Raj - 1. '(w Biblii) ogród, w którym przebywali pierwsi ludzie, Adam i Ewa' (Sstp).

${ }^{54}$ Rozkosz - 1. 'najwyższa przyjemność, zmysłowa lub duchowa, przyjemne doznanie', 2. 'to, co wywołuje przyjemne odczucia, przyczyna przyjemnych doznań, radości, wesela', 3. 'radość, wesołość (Sstp).

${ }^{55}$ Miasto - 1. 'miejsce' (Sstp.).

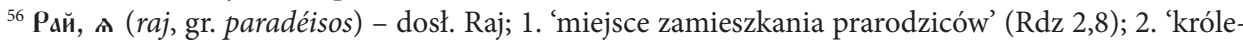
stwo wiecznej szczęśliwości’ (Łk 23,43) (A. Znosкo, Słownik cerkiewnosłowiańsko-polski, Białystok 1996, cetera: SCP).
} 
next to Eden (Gn 4,16) (VA, BL, BW) // GAfH8 (FS). It should also be noted that while in the examples quoted above all translators consistently used the lexeme rozkosz (pleasure), the $16^{\text {th }}$ century Polish translation BL shows a tendency to use the word raj (paradise) at the expense of the appellative rozkosz: Ray (Gn 2,10) // Ray rofkoszy (Gn 2,8; 2,15; 3,23; 3,24) (BL). In some older translations which were based on the Latin text of Gn 4,16 an amplification is performed, the purpose of which is to explain, at least to a certain extent, the inconsistence in using various variants of the name: od raya gejz to flowye Eden (BZ), ráj, ješto slóve Eden (OL). Such specifying of some biblical realities is related to the technique of medieval liberal translations, which were chiefly aimed at a simple audience ${ }^{57}$. Here, it is worth pointing out that despite his faithful pursuit of the Latin text, Jakub Wujek - displaying his regular conscientiousness - on the margin of Gn 2,10 and 2,15 jotted down variants which were in the spirit of the Hebrew text and functioned as proper names: abo z Edena (Gn 2,10), abo w sadu edeńskim (Gn 2,15).

The issue of translation equivalents of the said name looks slightly different in the translation of $\mathrm{BO}$. The solutions there alternate between the translations from original languages and VG, although the influence of the Greek text (LXX) dominates: въ єдєнћ (Gn 2,8; 2,10; 4,16), раи пича ${ }^{58}$ (Gn 2,15; 3,23; 3,24) (BO). Such a state of affairs is connected with the complexity and variety of sources of the BO, among which one can find e.g. translations by Skoryna, selected old-Czech and old-Polish versions, the LXX and the $\mathrm{VG}^{59}$.

A strong relationship between the translation base and the selection of an appropriate translation equivalent of the name Eden is also clearly visible in the excerpted translations in their reference to other Books of the Bible. The Hebrew text $(\mathrm{BH})$ uses the form Eden in the same meaning as it is used within $\mathrm{Gn}$, in: Ez 28,$13 ; 31,9 ; 31,16 ; 31,18 ; 31,18 ; 36,35$; Il 2,3. And its example is faithfully followed by translations from original languages: Eden (BRZ, GD, KR, BT, HG, EK, JR), although they do happen to apply both the noun and adjective variant: EdeM (Ez 28,13) (S, BC, D), Едем (31,18; 31,18; 36,35) (BC) // едемски (Ez 31,9; 31,16; Il 2,3) (S, BC, D), (Ez 31,18; 31,18; 36,35) (S, D). At this point, translations based on the VG consistently utilise appellativum, whose presence stems from the Latin text (Ez 28,13: deliciae; Ez 31,9; 31,16; 31,18; 31,18: voluptas; Ez 36,35; Il 2:3: hortus

\footnotetext{
${ }^{57}$ Cf. I. KwILECKa, Rola przekładów biblijnych w rozwoju języka polskiego od Średniowiecza do Renesansu, [in:] EAdEM, Studia nad staropolskimi przekładami Biblii, Poznań 2003, p. 265-279 (269-270). ${ }^{58}$ Пица, и (piszcza, gr. broma) - (piszcza, gr. broma) - 'żywność, pokarm' (Kpł 25,37; Hb 6,7); райскал

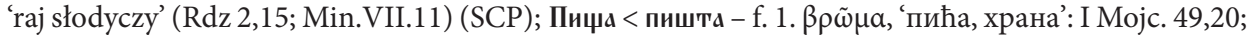

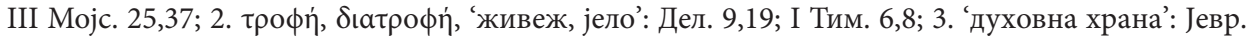

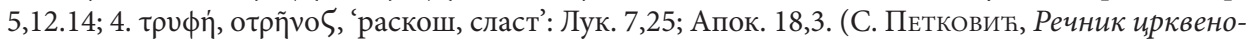
словенскога језика, Сремски Карловци 1935); Пища - ж. старин. 1. 'храна', 2. прен. 'нещо, което поддържа и развива духовната природа на човека' (BTR).

${ }^{59}$ Cf. К истории отечественной Библии (130-летие Синодального перевода), www.rpsc-spb. ru/2010-12-23-14-47-16 [22 IV 2016].
} 
voluptatis): пища рал (Ez 28,13; 31,9) (ВО), древєса пища (Ez 31,16; 31,18; 31,18) (BО), градть пищ'ныи (Ez 36,35) (BO), раи пища (Il 2,3) (BO), w rofkoszach raiu (Ez 28,13) (BL, BW), drzewa rofkoszy (Ez 31,16; 31,18; 31,18) (BL), (Ez 31,16) (BW), drzewa rofkoszne (Ez 31,9) (BL), (Ez 31,18; 31,18;) (BW), ogrod rofkoszy (Ez 36,35; Il 2,3) (BL), ogrod rofkoszny (Ez 36,35; Il 2,3) (BW), ray (Ez 31,9) (BW), rozkoš (VA).

At this point, it is again noteworthy to pay attention to the $16^{\text {th }}$ century translation by Symon Budny, who recognised the Hebrew text as the base of the original and this time, surprisingly enough, decided to apply a solution used in the VG: ray ro/koszny (Ez 28,13), drzewa ro/koszne (Ez 31,9; 31,16; 31,18; 31,18), sad ro/koszny (Ez 36,35; Il 2,3) (BB). It was only in the margin that he wrote down: abo Hedeńskie (drzewa) (Ez 31,9), abo Hedeński (sad) (Ez 36,35), thus indicating the possibility to use nomen proprium there, but without adding that such a solution is imposed by the Hebrew text $(\mathrm{BH})$.

The clear dividing line between translations from original languages and the remaining ones is not marked in reference to Is 51,3 either. In the Hebrew text (BH) the proper name Eden is used, which is continued in the Polish BT, the Czech HG, EK, JR, and the South-Slavic: Edeм (BC, D). Other versions based on the original text use appellative expressions: ogrod rofkoszny (BRZ), prererozkošný (KR), the common noun: paŭ (S), раи (BO), or descriptive structures: uczyni puszcze jego bardzo rozkoszna (GD). The $\mathrm{BB}$ offers appellativum ray with the following marginal gloss: abo iako sad. Translations from the VG (Latin: deliciae) consistently have appellativum, which is a semantic calque of the Latin lexeme: rofkoszy (BL), rozkosze (plural) (BW), rozkoše (VA).

In the Bible, the name Eden appears not only in the context of the paradise garden, but also as a description of a national and ethnic group (4Reg 19,12; Is 37,12; Ez 27,23). In the text of $4 \operatorname{Reg} 19,12$ we can read about $B^{e} n \hat{e}$ 'Eden, i.e. the Arameans who resided in Bit-Adini, an area mentioned in cuneiform scripts and located between the Balikh and the Euphrates Rivers. Mentioning the sons of Eden, the authors of the Bible most likely had in mind the inhabitants of the Aramean state of Bit 'Adini, the capital city of which was Til Barsip (modern Tell Ahmar). The settlements of this state were on both banks of the middle course of the Euphrates, east of Aleppo (cf. KR 202).

Regarding the aforementioned locations, translations from original languages offer the following solutions: 1) a phrase containing a proper name, e.g. syny Eden (4Reg 19,12; Is 37,12) (BRZ, KR, GD, EK) (HG: 4Reg 19,12), синовете на Еден (4Reg 19,12; Is 37,12) (S), 2) a phrase with a possessive adjective derived from the place name, e.g. syny Edenowe (4Reg 19,12; Is 37,12) (BB), Еденовите синове (4Reg 19,12; Is 37,12) (BC), синове Еденове (4Reg 19,12; Is 37,12) (D), 3) an ethnonym in the noun form, e.g. Edeńczycy (Ez 27,23) (BRZ), Edanici (4Reg 19,12; Is 37,12) (BT), Edenité (JR), 4) nomen proprium: Eden (Ez 27,23) (KR, GD, HG, 
EK, JR), Edon (Ez 27,23) (BT), Hiden (Ez 27,23) (BB), Еден (Ez 27,23) (S, BC, D), 5) a name Semitism, e.g. Bit Adin (Is 37,12) (HG). The footsteps of the Greek LXX are followed by the BO: сйы адон (LXX: E $\delta \varepsilon \mu)(4 R e g$ 19,12), no name (LXX: $\chi \omega ́$ pa (?)) (Is 37,12), no name (LXX: none) (Ez 27,23).

Even though translations based on the VG (4Reg 19,12; Is 37,12: filios Eden; Ez 27,23: Eden) faithfully follow in its footsteps, e.g. syny Eden (4Reg 19,12; Isa 37,12), Eden (Ezek 27,23) (BL, BW), Eden (4Reg 19,12) (BZ), some formal variation within translation equivalents, e.g. Eden (4Reg 19,12; Ez 27,23) (VA) next to the adjective Edenský (Is 37,12) (VA). The FS in 4Reg 19,12 has the adjective form: и сынОВ' $G_{\text {AEHAh }}{ }^{60}$.

Another biblical fragment which is noteworthy due to the mention of Eden it contains is Am 1,5. In the BH, the phrase Bet Eden is used, whereas in the LXX it is translated as Xappav, and in the VG as domus Voluptatis. The contemporary biblical exegesis provides no answer to the question regarding what name specifically is referred to there. Bet-Eden is identified as Bit-Aidini, a settlement on the banks of the central course of the Euphrates River known from the Assyrian records. It is also worth noticing that the equivalent used in the VG functions as a symbolic name of Damascus: domus Voluptatis 'dom rozkoszy/house of pleasure $^{361}$. Thus, the appellativisation of the Hebrew name was influenced by the LXX and the VG, which in consequence impacted the variety of equivalents in all individual translations into national languages.

In this case, the excerpted Slavic translations show significant discrepancies, which only to a limited extent depend on the source of the translation. First of all, it is noteworthy to analyse Czech translations. The texts based on the original sources: 1) take the form of Bet-Eden (HG, JR), 2) have a phrase consisting of a native noun and a foreign name: dim Eden (KR), 3) and incorporate a solution adopted from the Latin tradition: Dům rozkoše (EK). The appellative phrase di̊m rozkoše, which is a semantic calque of the Latin version, was used in the VA translation that is based on the Latin VG. The situation is similar as far as Polish translations are concerned. Those made from original languages take the tophony Bet-Eden (BT), Beteden (BRZ). The author of the BB and the GD decided to arrive at a certain type of compromise, which consists in the use of the Hebrew name and the semantic calque of the Latin word domus, as applied in the VG: dom Heden (GD), dom Hedenowy (BB). Analogically, the same technique is applied in South-Slavic translations: дом Еденов (S, BC, D). Translations based on the Latin text of the VG continue using its solutions, abandoning the proper nature of the name: dom rofkoszy (BL, BW), even if the author of the BW inserted a marginal gloss where he noted down the Hebrew form: $z$ Beth-edena.

\footnotetext{
${ }^{60}$ For Is 37,12 and Ez 27,23 there are no variants within the FS (untranslated books).

${ }^{61}$ Cf. Księgi proroków mniejszych. Ozeasza - Joela - Amosa - Abdiasza - Jonasza - Micheasza. Wstęp

- Przekład z oryginału. Komentarz, ed. S. ŁACH, Poznań 1968, p. 190.
} 
In a short article, it is virtually impossible to scrutinise all translation variants of the selected source form in the possibly widest corpus of biblical translations. Thus, it was necessary to focus exclusively on several selected Slavic translations, the choice of which was, however, performed on numerous various criteria. The analysis of translation equivalents of the Hebrew name Eden in the excerpted texts renders it possible to notice the variety of meaning and formal equivalents, and, even more interestingly, the relationships and influences between translations (especially within the denominational class or based on any source text: the Hebrew original, the LXX, the VG). At the same time, it demonstrates the difficulties that the authors of Slavic translations experienced while struggling with the demanding linguistic matter. Such problems stemmed from a variety of factors: the genetic and structural discrepancies between Semitic and Slavic languages, additionally magnified by the influence of the first translations of the Bible (the Greek LXX and the Latin VG), different outlooks on reality in cultures that are so distant to one another (which is also connected with the specific standing of proper names in the Bible that usually identified and characterised an object), the incongruence of certain biblical realties to the reality of the Slavic territory, religious conditionings, and - in the case of the earliest Slavic translations - also the incomparably lower biblical knowledge in comparison to our times. It must also be emphasised that some proper names which were particularly expressive in terms of ideology (including beyond any doubt the proprium Eden) alternate between their proper and common meaning in translation. The analysis of such meanings and use is so valuable, since it also has its repercussions in individual national languages, cf. e.g. the use of the name Eden as a synonym to 'kraina szczęśliwości/the land of happiness' in various tongues.

In conclusion, attention should be paid to one more aspect of the conducted research. One of the premises of drafting this article was also the wish to stress the validity of any effort put into making mini-monographs of that kind, the purpose of which is to describe translation equivalents of any given name in a possible broad corpus of translated texts. In the future they may contribute to the making of a larger synthesis, in which the analysis of translation variants of individual biblical names could become starting point to indicate basic tendencies and mechanisms within the scrutinised issues, and common features and discrepancies in any given individual Slavic translations. 


\section{Bibliography}

\section{Sources}

Bible svatá aneb všecka svatá písma Starého i Nového Zákona podle posledního vydání kralického z roku 1613, http://www.etf.cuni.cz/ rovnanim/bible/k/Mt1.php [21 IV 2016].

Biblia hebrajska, http://tanach.leszek-kwiatkowski.eu/ [15 IV 2016].

Biblia Królowej Zofii (szaroszpatacka): wraz ze staroczeskim przekładem Biblii, ed. S. URBAŃCZYк, V. Kyas, Wrocław 1965-1971.

Biblia Sacra Vulgata, http://www.drbo.org/lvb/ [20 IV 2016].

Biblia Swięta tho iest Księgi Starego y Nowego Zakonu, wlaśnie z żydowskiego, greckiego y łacińskiego, nowo na Polski ięzyk z pilnościa y wiernie wyłożone.... drukowano w Brześciu Litewskim z roskazania a nakładem... Mikolaia Radziwila... Roku Pańskiego [1563] miesiąa Wrzesnia dnia czwartego, http://mbc.malopolska.pl/dlibra/docmetadata?id=83322\&from= publication [19 IV 2016].

Biblia święta, to jest księgi Starego i Nowego Przymierza z żydowskiego i greckiego języka na polski pilnie i wiernie przetłumaczone, Gdańsk 1632, http://www.bibliagdanska.pl/biblia. php?d [12 IV 2016].

Biblia To Iest Księgi Starego Y Nowego Testamentu, Według Łacińskiego przekładu starego, w kościele powszechnym przyiętego, na Polski ięzyk z pilnością przełozone [...] Przez [...] Iakuba Wuyka [...], http://www.dbc.wroc.pl/dlibra/doccontent?id=12433 [11 IV 2016].

Biblia to jest Księgi starego i Nowego Przymierza. Księgi Nowego Przymierza Kto pospolicie Nowym Testamentem zowa $z$ wielka praca y pilnym poprawieniem $z$ Greckiego na Polski ięzyk przettumaczone, http://www.dbc.wroc.pl/dlibra/docmetadata?id=4263\&from=publication [10 IV 2016].

Biblia to jest księgi Starego i Nowego zakonu na polski język z pilnościa według łacińskiej Biblii, od Kościoła krześcijańskiego powszechnie przyjętej, nowo wyłożona..., Kraków 1561, http://jbc.bj.uj. edu.pl/dlibra/doccontent?id=230780\&from=FBC [12 IV 2016].

Biblija ili Sveto pismo Staroga i Novoga zavjeta, http://www.pouke.org/svetopismo/ [15 IV 2016].

BJBLJ Cžeská to gest Swaté Pjsmo Podlé Starožitného a Obecného Latinského od Wsseobecné Cýrkwe Swaté Ržjmské potwrzeného a vžjwaného Přeloženj [...] W Starém Městě Pražském w Kollegi Sw. Kljmenta Towaryšstwa P. Gežjsse skrze Joachyma Jana Kamenického Faktora Léta M. DCC. XV. [= 2. díl] Prorokowé A Knihy Machabeyský. Nákladem Dědictwj Swatého Wáclawa [...] Léta 1712. [= 3. dill Druhý djl Biblj totižto Nowý Zákon Podlé starého obecného Latinského textu, od samospasytedlné Ržjmské Katoljcké Cýrkwe schwáleného, a až posawad wtéž Cýrkwi vžjwaného [...] Léta Páně 1677 [...] [= 3. díl, NZ].

Český ekumenický překlad: Písmo svaté Starého i Nového Zákona podle ekumenického vydání z r. 1985, Praha 1987, http://www.biblenet.cz/ [23 IV 2016].

Jeruzalémská bible. Písmo svaté vydané Jeruzalémskou biblickou školou, Praha 2005, http://www. jeruzalemskabible.cz/ [24 IV 2016].

Novum Testamentum Graece et Latine, ed. E. Nestle, K. Aland, Stuttgart 1984, https://sites.google. com/site/nestle1904/mat/23 [20 IV 2016].

Písmo svaté Starého zákona, ed. F. Kotalík, J. Merell, Praha 1955-1958.

Pismo Święte Starego i Nowego Testamentu w przekładzie z języków oryginalnych, ed. K. DyNARSKI, ${ }^{1}$ Poznań 1965, ${ }^{4} 1983$, http://biblia.deon.pl/ [15 IV 2016].

Septuaginta, ed. A. RAHLFs, ${ }^{9}$ Stuttgart 1971, http://www.ellopos.net/elpenor/physis/septuagintgenesis/41.asp?.pg=5 [21 IV 2016]. 
Staročeská bible Drážd’anská a Olomoucká: kritické vydání nejstaršiho českého překladu bible ze 14. století. 3, Genesis - Esdráš, ed. V. Kyas, Praha 1988.

Библия сиреч Книгите на Свещеното Писание на Вехтия и Новия Завет, http://www.bgpatriarshia.bg/index.php?file=bible_old_testament.xml [16 IV 2016].

Библия сиречь книги Ветхого и Нового Завета на языке словенском, Острог 1581.

Библия, сиреч Священото писание на вехтий и новий завет. Вярно и точно преведено от първообразното, Цариград 1871, http://biblia.bg/index.php?k=30\&g=1\&tr2=1 [16 IV 2016].

"Библия руска" выложена доктором Франциском Скориною из славного града Полоцка, Богу ко чти и людем посполитым к доброму научению, Прага 1517-1519.

\section{Secondary literature}

BIEŃKowsKa D., Nazwy własne i formy od nich derywowane w XVI-wiecznych przekładach tekstów ewangelicznych, AUL.FL 27, 1993, p. 9-14.

BieŃKowsKa D., O niektórych problemach przekładu biblijnego (na przykładzie miast, miasteczek i wsi), [in:] Biblia w kulturze polskiej, ed. S. RzePCZYŃsKi, Słupsk 1996, p. 215-228.

Bjelajac B., Sveto pismo u Srba, Beograd 1997.

Breza E., Odmiana nazw własnych w Nowym Testamencie Biblii Wujka i Biblii Tysiąclecia, [in:] Biblia a kultura Europy, vol. I, ed. M. KAMIŃsKA, E. MAŁEK, Łódź 1992, p. 152-159.

CIEŚLIKowa A., Jak „ocalić w tłumaczeniu” nazwy własne?, [in:] Między oryginałem a przekładem II. Przekład, jego tworzenie się i wpływ, ed. J. Twardzikowa, M. Filipowicz-Rudek, Kraków 1996, p. 311-320.

Cieślikowa A., Onimizacja, apelatywizacja a derywacja, [in:] Onimizacja i apelatywizacja, ed. Z. Abramowiczowa, E. Bogdanowicz, Białystok 2006, p. 47-56.

Dittmann R., Místní jména v českých překladech Starého zákona, Olomouc 2009.

DŁugosz-Kurczabowa K., Apelatywizacja biblijnych nazw własnych w języku polskim, Wrocław-Warszawa-Kraków 1990.

DŁugosz-Kurczabowa K., Onomastyka Nowego Testamentu, SOcc 46-47, 1989-1990, p. 71-88.

Encyklopedia katolicka, vol. XVI, ed. S. WILK, Lublin 2012.

Friedelówna T., Biblijna onomastyka w staro-cerkiewno-słowiańskim Psałterzu synajskim, AUNC. FP 40, 1993, p. 3-25.

KаміŃsкa M., Onomastyka biblijna tekstów przekładowych jako problem badawczy, [in:] Onomastyka literacka, ed. M. BIOLIK, Olsztyn 1993, p. 321-328.

KlaweK A., Onomastyka biblijna, On 7, 1961, p. 403-416.

KoмÁrek K., Apelatywizacja w toponimii biblijnej, [in:] Onimizacja i apelatywizacja, ed. Z. AвrAMowiczowa, E. Bogdanowicz, Białystok 2006, p. 113-117.

KoмÁreк K., Osobní jména v českých biblích, Olomouc 2000.

Księga Rodzaju. Wstęp - Przekład z oryginału. Komentarz, vol. I.1, ed. S. ŁACH, Poznań 1962.

Księgi proroków mniejszych. Ozeasza - Joela - Amosa - Abdiasza - Jonasza - Micheasza. Wstęp - Przekład z oryginału. Komentarz, ed. S. Łach, Poznań 1968. 
KwILECKa I., Rola przekładów biblijnych w rozwoju języka polskiego od Średniowiecza do Renesansu, [in:] EADEM, Studia nad staropolskimi przekładami Biblii, Poznań 2003, p. 265-279.

KWILECKa I., Średniowieczna Biblia francuska a najstarsze zachodniosłowiańskie przekłady biblijne, [in:] EADEM, Studia nad staropolskimi przekładami Biblii, Poznań 2003, p. 153-175.

Malec M., Onomastyka w „Rozmyślaniu przemyskim”, Po 22-23, 2003, p. 345-390.

Moszyński L., Hebr. ha - Adam: nomen apellativum - nomen proprium w renesansowych przekładach biblijnego opisu życia pierwszego człowieka (Gn I 26 - V5), Sla 61, 1992, p. 503-508.

Moszyński L., Szymon Budny jako onomasta. 3. Ojkonimia, [in:] Ogród nauk filologicznych. Ksiega Jubileuszowa poświęcona Profesorowi Stanisławowi Kochmanowi, ed. W. Chlebda, M. BalowSKI, Opole 2005, p. 445-455.

Naumow A., Franciszek Skoryna z Połocka jako biblista, KMc 18, 2009, p. 166-173.

Odelain O., R. SÉGuineau, Dictionnaire des noms propres de la Bible, Paris 1978.

OsadniK W., Teoria wielosystemowa i rodzaje ekwiwalencji w przekładzie, Katowice 2010.

Rienecker F., Maier G., Leksykon biblijny, ed. W. Chrostowski, Warszawa 2001.

Rospond S., Onomastica sacra w Nowym Testamencie: Ewangelia św. Marka w świetle nazewnictwa, On 28,1983 , p. 5-32.

Rospond S., Onomastica sacra. 3. Ewangelia św. Mateusza w świetle nazewnictwa, RHu 30-31.6, 1982-1983, p. 183-191.

Slovník spisovného jazyka českého, http://ssjc.ujc.cas.cz/search.php?hledej=Hledat\&heslo= zahrada \&sti=EMPTY\&where=hesla\&hsubstr=no [20 IV 2016].

Słownik jezyka polskiego, ed. W. Doroszewski, vol. I-XI, Warszawa 1996-1997.

Stownik staropolski, ed. S. URBAŃCZYK, vol. I-XI, Kraków 1953-2002.

Słownik wiedzy biblijnej, ed. B.M. Metzger, M.D. Coogan, Warszawa 1997.

SolAK E., Nowobułgarska Biblia i jej język, Kraków 1997.

Sowa F., Osobowe nazwy własne w polskich przekładach Biblii, [in:] Biblia a kultura Europy, vol. I, ed. M. Kamińska, E. MaŁeK, Łódź 1992, p. 81-85.

Umińska-Tytoń E., Nazwy osobowe w tzw. dynamicznym przekładzie Nowego Testamentu, [in:] Onomastyka literacka, ed. M. BIoLIK, Olsztyn 1993, p. 329-335.

ZARĘBSKi R., Nazwy osobowe w polskich przekładach Nowego Testamentu, Łódź 2006.

ZARĘBSKI R., Tłumaczenie obcych nazw geograficznych $w$ dawnych i wspólczesnych polskich przekładach Nowego Testamentu, [in:] Studia nad słownictwem dawnym i wspótczesnym języków słowiańskich, ed. J. Kamper-Warejko, I. Kaproń-Charzyńska, J. Kulwicka-Kamińska, Toruń 2007, p. 113-123.

Znosкo A., Słownik cerkiewnosłowiańsko-polski, Białystok 1996.

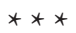

Български тълковен речник, еd. Д. Попов, София 2001.

Донев Д., Историята на българската Библия, http://old.evangelskivestnik.net/_statia.php? mysid=37 [20 IV 2016].

ЗАремьски Р., Номинаиии с определителна филиативна дескрипиия в Зографския кодекс на фона на някои славянски преводи на Евангелието, Pbg 37.4, 2013, p. 81-94. 
Иванова Д., Традиция и приемственост в новобългарските преводи на Евангелието. Текстотогия и език, Пловдив 2002.

Иванова Д., Езикът на Библията. Бътгарски синодален превод 1925 г., Пловдив 2003.

К истории отечественной Библии (130-летие Синодального перевода), www.rpsc-spb.ru/2010 -12-23-14-47-16 [22 IV 2016].

Московљевић М., Речник савременог српског језика с језичким саветником, Београд 2000.

ПЕтковит С., Речник ирквенословенскога језика, Сремски Карловци 1935.

Чолова С., Към въпроса за библейските преводи в България, http://ebox.nbu.bg/pro/2\%20Zv.\%20 Cholova\%20+\%20r.pdf [28 IV 2016].

\begin{abstract}
The authors study different equivalents of the Hebrew word Eden in selected old and new Slavic translations of the Bible. The equivalents of this lexeme have been excerpted from several Slavic translations of the Bible, which were selected on the basis of diverse criteria. The translations are presented chronologically and old translations are opposed to the new ones. They represent three groups of Slavic languages: West Slavic, East Slavic and South Slavic and are connected with the base of translation, i.e. the original text and/or Greek or Latin text. They can also be classified according to religious denomination and the strategy of the translation.

The observation of those equivalents enables us to see not only their variety and mutual influence among translations but also the struggle of Slavic translators with a very difficult language matter. Many factors were important in that struggle: genetic and structural distances between Semitic and Slavic languages, different perceptions of reality in distant cultures, the discrepancy between biblical and Slavonic realities and the influence of religious denomination. Another important factor was the state of biblical knowledge at the time - incomparably poorer in the case of the oldest Slavic translations in comparison to modern ones.
\end{abstract}

Keywords: Slavic old and new translations of the Bible, proper names, Eden.

Agata Kawecka

Uniwersytet Łódzki

Wydział Filologiczny

Katedra Filologii Słowiańskiej

ul. Pomorska 171/173

90-236 Łódź, Polska/Poland agata.kawecka@uni.lodz.pl

Rafał Zarębski

Uniwersytet Łódzki

Wydział Filologiczny

Instytut Filologii Polskiej

Katedra Historii Języka Polskiego

ul. Pomorska 171/173

90-236 Łódź, Polska/Poland rafal_zarebski@uni.lodz.pl 